\title{
The effect of oral performances in audiences' minds and behaviour
}

\author{
SANTOSA
}

\begin{abstract}
As a means of communicating thoughts, gamelan performances affect the way audiences construct their worldview. More than that, listeners in villages believe that performances can affect people's behaviour. Performances may be deeply influential in the creation of fundamental social values such as in-group integrity, feelings of unity and peace in the community. All this demonstrates that in villages, arts are not autonomous entities; people value the arts as an integral domain with other social activities.

KEY WORDS

Gamelan performance, aesthetics, musical communication, audiences, integrity.
\end{abstract}

\section{INTRODUCTION ${ }^{1}$}

Musical communication does not attract scholars from many fields. Scientists in communication studies probably believe that the topic does not contribute to the development of major theories because musical communication differs from what they consider as the major means of communication: oral and written communication. People in artistic communities, on the other hand, may think that communication is taken for granted because the people involved musicians, audiences, patrons, hosts, guest of ceremonies - in performances

1 This paper is a revised version of parts of my dissertation Constructing images in Javanese gamelan performances: communicative aspects among musicians and audiences in village communities, $\mathrm{PhD}$ thesis, University of California Berkeley (2001). The original version of this article was presented at the "International Oral Tradition Seminar", Oral Traditions Association (OTA), Jakarta, 1-4 Desember 2006.

SANTOSA is graduated from the Ethnomusicology Program of University of California at Berkeley in 2001. He is a faculty member in the Department of Ethnomusicology, Institut Seni Indonesia (ISI) Surakarta and he taught gamelan in the Philippines, Singapore, Australia, and the United States. He published the book Etnomusikologi Nusantara; Perspektif dan masa depannya (2007) and an article "Gamelan music; Meanings and contexts in village rituals and celebrations", Asian Musicology Vol. 13: 31-112 (2008), published in Korea. Santosa may be contacted at: mastosa2003@yahoo.com.

(C) 2010 Faculty of Humanities, University of Indonesia 
do not really care about the process. Alternatively, they may believe that such communication does not exist during performances. They may think that gamelan performances are mainly designed for aesthetic appeal and do not contain any communicative aspects whatsoever.

I will argue in this paper that a gamelan performance contains what I call 'musical communication' (see Santosa 2008). More than that, musicians are aware of this mode of sending messages to audiences who receive these messages in a variety of ways. It is through this kind of communication that in the mind of the audience a performance comes to live.

I would like to explore how a gamelan performance affects the way individuals think and behave and how it affects community values. I will begin with the issue of performance and the "future" in which people connect other domains to the messages and values conveyed by gamelan music. This leads to the next issue, namely that a performance has an actual effect on real life. I will emphasize that the way villagers think about a performance is not the same as that of other people, scholars, such as Albrecht (1970) analysed. There is a belief that the artistic domain is able to affect people's behaviour and to provide a sense of integrity among the members of a group. These topics demonstrate that arts in villages are not autonomous entities; people value arts as an integral domain with other social activities.

\section{MESSAGES AND THE FUTURE OF SOCIETY}

Among village people, gamelan performances contain values of both the present and the future. They strongly belief that the psychological effect on social values of gamelan performances is not limited to the here and now. Rather, this psychological effect extends to the future in order to achieve the ultimate goals that are the community's ideals. It is involved in on-going processes of reflection through which self-imagination and the construction of the aural memory of performances occur. This process takes place because "music is essentially motion through time" (Nattiez 1990: 21), and it is in this movement that people construct images they eventually transform into notions about social values.

The question is how this process occurs during gamelan performances. How do performances mediate the values of the audiences who are present during these performances? We need to know the connection between the content of a gamelan performance and the values prevalent in the community, considering that performances do not exists in a vacuum but rather in constantly changing community contexts. To investigate this we may ask why people want to understand the messages conveyed and what the use of this content is in their lives. How do these messages affect social values?

In the audiences' minds, messages have a special significance. Through musical communication people want to elevate their experiences to new and "fresh" psychological levels in which they can expect thoughts to be referential to their behaviour. They want to re-shape, re-define, and re-interpret what they have experienced previously. In a way, this is the "transformation" of 
their thoughts into guidelines for their conduct in life. Among the members of a gamelan community, it is believed that listening to gamelan music is a means to reach goals in a limited but also in a wider sense. A performance has an effect not only on individuals but also on the community at large for a much longer period than the duration of the performance. The content of gamelan performances may offer guidance for a person's life because it carries social values such as honesty, devotion, superiority, and spiritual wisdom. People perceive these values and exercise them in social contexts. This is common practice among audiences in village communities. Pak Mulyata, a senior person who has deep understanding of these values, said that the community uses them as guidance so that people will not do something wrong (ora nabrak-nabrak; literally, not to break rules) (personal communication 3 December 2007).

We also need to know how people make use of this "guidance", the term musicians and audiences commonly mention when they discuss the meaning and the content of gamelan music. Meaning and content do not exist instantaneously and only in the present, but are constructed through time and space. They are the result of what people have experienced earlier supplemented by subsequent experiences. For example, people who attain a happy state of mind from listening to gamelan music are satisfied when they have finished listening to it. In the meantime, however, this state of mind is stored in their memory and given new perspectives through new experiences. When they listen to other performances, they will obtain another state of happiness, one that reinforces their previous state of mind corresponding to the contemporaneous environment and the psychological atmosphere. This process occurs in particular environments and as these environments change the reaction to performances changes as well. It is clear that thoughts and states-of-mind are subject to change and that the idealization of the future is subject to change as well as audiences perceive new experiences.

A performance has a profound effect because during a performance, people are involved in exercising their minds and their imagination. Because this process takes place in these highly personal domains, people perceive the meaning of a performance as "real", and as an important life event in their community. One informant from a village commented on this issue as follows:

Seni punika nek purun perenungan rak nemokaken piyambak, ora kaya diguroni. Nek diwulang ya nek cocog karo karepe. Seni punika kados omongane wayang kene nyimpulaken piyambak, dados ora kudu-kudua dinut. Gandheng ingkang manggihaken badanipun piyambak mestenipun nggih dipuncocogaken (Jumadi, 5 December 2007).

(When people think of the meaning of art, they can find the content by themselves, unlike [when they are] being taught. If they are taught it may not be suitable for their intentions. Art is like the dialogues in wayang (shadow-theatre) performances in which we can infer [their content] by ourselves, people do not have to follow the thoughts. Since we find the meaning ourselves, we choose the one that is proper to our thoughts). 
The reason why people are involved in on-going processes of redefining the value of gamelan performances is that the reaction to each performance is a psychological state that changes not only in time and space but also under changed circumstances. This state of mind reacts to previous meanings that are given new perspectives by using input from the new context. When people say that the meaning of performances is in the context in which performances are staged, it means that their meaning is inherently contained within the community; individual persons interpret this meaning by either consciously or un-consciously taking the context into account. In dealing with this issue, Umberto Eco rightly commented that what occurs during a performance is not something that existed before the performance but rather what is constructed by audiences during that performance in a process that continues after the performance has ended. He believes that what musicians present is an empty form and that audiences may elicit meaning through active efforts during the performances. Eco said: "The message is represented as an empty form, to which one can attribute many possible meanings" (Nattiez 1990: 21).

What I have discussed so far implies that artistic performances can have a significant role in a community. Among the ideal values musicians and audiences may experience when they attend performances are guidance, reference, and the philosophical foundations of life. In their daily lives, these values can have different meanings depending on the situation. For example, when the environment in which people live does not provide the freedom to think and to speak to others, the role of these values becomes more significant than under "normal" circumstances in which people can freely express their ideas and thoughts. In this situation, the import of the message is even more poignant because it is this being "contrary to the fact" of what people experience in their daily lives that provides truth to their lives. When people do not trust their leaders and others, for example, the value of art can offer alternative guidance for behaviour. Or, at least it can be a medium to glimpse an image of the domains of lives that are free from pressure, distress, and controversy. Mudji Sutrisno believes that with art people can "breathe" more freely and inhale "fresh air" in a new situation. Commenting on this, he wrote:

Implisit di dalam pembahasan di atas, sesungguhnya mau menyatakan kepada kita bahwa "estetika" atau ruang seni, tidak hanya sebagai pelengkap kehidupan, melainkan juga dibutuhkan untuk oasis dan ruang menghirup udara segar (Sutrisno 1998: xiv).

(Implied in this discussion is that [art] wants to tell us that aesthetics do not only adorn people's lives, but are also needed to provide an oasis and room to inhale fresh air).

It is in this context that the Mangunjayan group, the former student-soldier group (Bekas Tentara Pelajar) exists in Jakarta. The members of this group want to rehearse weekly, but the rehearsals are not a means to achieve high values through gamelan music; for them gamelan music is a medium for the achievement of other social values than the "serious" content of the music. 
They think that life in Jakarta Metropolitan City is full of pressure, tension, strain, and stress, and by being active in gamelan rehearsals they can rid themselves of the pressing routines of daily city live.

What I have discussed above shows that people react to gamelan music in various ways. No matter what they think of the music, we can infer that they react to gamelan music in relation to their near or more distant future life. One of the possible values in which people put ideals and aspirations is spiritual wisdom and people rely on that value. However, other people can put value on other aspects such as the release of tension or the stimulation of solidarity among members of the group. Albrecht discussed this issue in his article "Arts as an Institution" and he believed that:

In our society, individuals may use art as recreation, as escape, as consolation, as a release of tension or whatever, and the social consequences may include those suggested (Albrecht 1970: 12).

By using the examples I mentioned previously we can infer that messages from art are not single but rather multiple entities depending to how people see art and from which angle they want to make sense of it (Santosa 2001). It is in this process that gamelan performances have meanings not only for those in artistic circles but also for the members of the community who intend to improve their future.

\section{BENIGN AND MALIGN EFFECTS OF GAMELAN MUSIC}

The effects of gamelan performances can be either benign or malign depending on the contexts prevalent in the gamelan communities. The effects of gamelan music are not limited to people's thoughts but extend into their daily lives.

As a rule, people want to extract good connotation, not the evil ones, because performances are considered to become real in their life. For example, during ceremonies, a host wants to acquire blessing (Javanese: angsar), the benign effect of gamelan music that may happen in the context of family and villagers. Contrarily, misfortune (Javanese: walat, literally, heaven-sent retribution) is the evil effect of a performance people do not want to get.

How does this logic of consequence work in the gamelan community? As I previously explored, associations connected with gamelan not only take place in the minds of audiences but are "transferred" into the real world. People use an analogy to "concretize" the image that they get from performances and thus, images that were initially in the form of ideas become concrete in their real life contexts. People do not just construct worldviews; they also "create" a reality that is based on these views. The image becomes "real" giving people more meanings they can use for specific purposes in their social context.

Gamelan performances are commonly considered to deal with serious issues because through these performances people can reach the kind of mental state they consider to be the ultimate goal in life (see Illustration 1). It is in this context that performances are considered to have value. Pak Jumadi, much like Pak Saguh and many other informants, said that gamelan music 
does not have an "ordinary" but a "high" value (bobot inggil) because it has a beneficial effect. He said:

Menawi musikipun endah-endah lan bobotipun inggil saged nuwuhi raos katentreman. Nek cara wong Jawa angsare apik (Pak Jumadi, personal communication, 15 February 1999).

(If the music is beautiful and the value is high it can stimulate a feeling of being at peace. Javanese people say it has a good effect).

The positive effect of a gamelan performance can be psychological or "metaphysical". Under normal circumstances, when gamelan is performed during a ceremony, a gendhing can evoke emotions from the most superficial to the most solemn. Especially for those who have the competence to perceive these messages, the psychological effects can be deep.

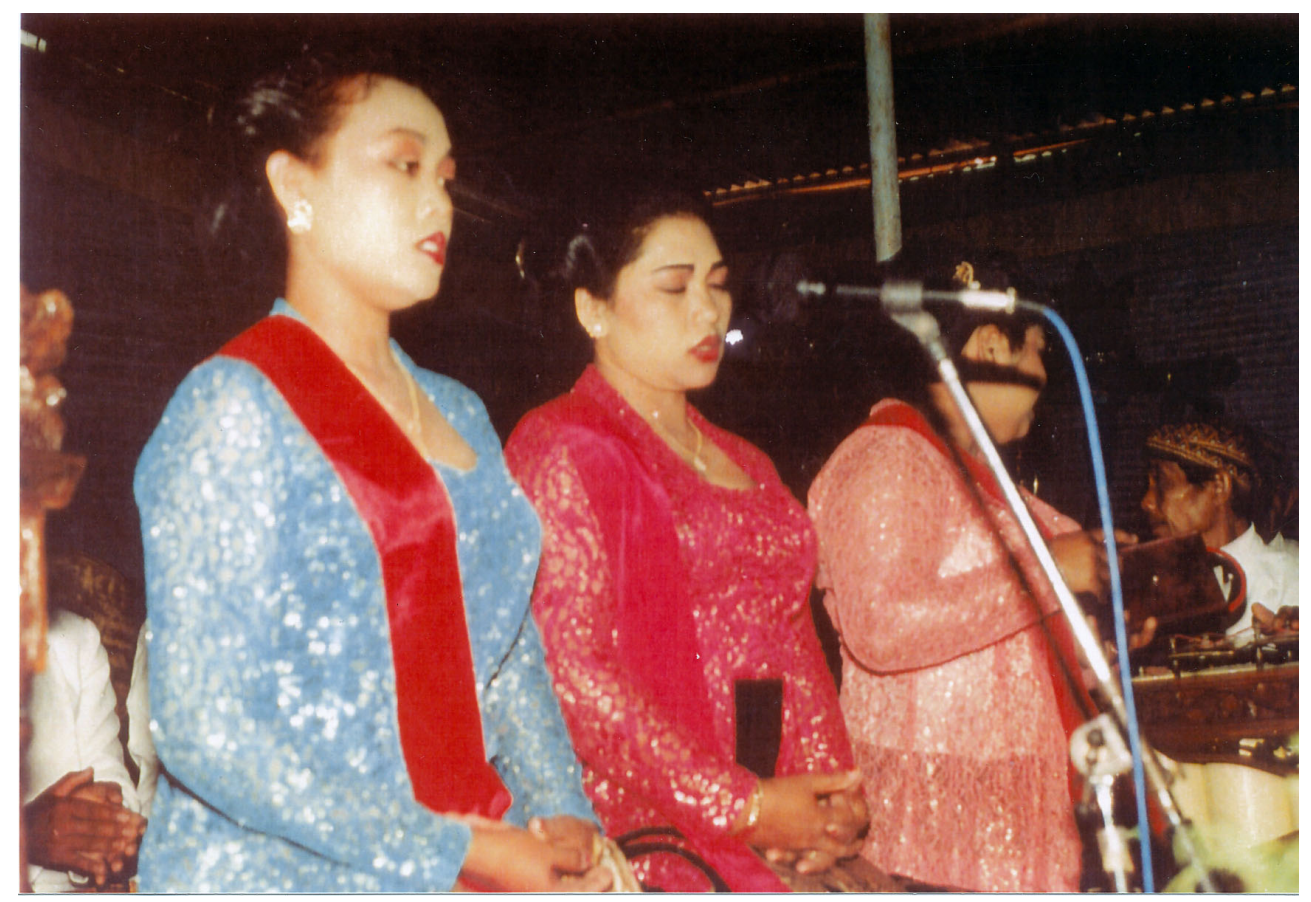

Illustration 1. Gamelan musicians and singers perform in village ceremonies to mediate values in the community; Photograph by the author.

However, at certain moments and in certain environments musicians can play a certain gendhing and thus overstep its normal use. Usually this has to deal with nature when they want to rid themselves of something disturbing such as rain or thunder. Among musicians, for example, stories consistently circulate about the way a piece of music can be used as a mean to circumvent bad luck. For instance, Pak Saguh told me the following story (personal communication, 10 January 2006). Once it rained hard before the gamelan performance started and the musicians were concerned that if the rain did not stop no audience 
would show up. At that time, Pak Saguh was the leader of the group and he told the musicians to play the gendhing Pacul Gowang, ${ }^{2}$ and the rain stopped after they finished performing this particular gendhing.

Commenting on this, Pak Saguh said that a gendhing can have a certain power when musicians play it with serious intention, especially when they accompany it with prayer. In the case of Pacul Gowang above, he said, the musicians were able to obtain power because when they played it they also prayed intensely to God. The prayer and the gendhing together produced an intense atmosphere. Under this condition, the musicians had the power to cast a "spell" in order to stop the rain. Under normal circumstances, musicians would refuse to play that particular gendhing because they knew that it is not to be used for any ordinary purpose. Precisely because it is not performed in a normal situation, this gendhing has a certain power because it directs the thoughts of the musicians and the audience alike. The gendhing attracts the dimension of a particular psychological state eventually leading to a certain aura.

Musicians who believe in the effects on their lives of certain musical pieces use their imagination to construct reality, not only when they hear pieces that are properly performed but also when they are not performed in the proper context. For example, when Pak Saguh was on the way to participate in a recording session in Semarang, Central Java, the driver of the bus he and his friends took turned on a recording of the Gendhing Laler Mengeng, a piece that is considered to cause evil when performed in a normal situation. As he heard the music, Pak Saguh whispered to his friends that something would happen in Semarang. When they got to Semarang, the recording was cancelled. Pak Saguh said that the "cue" from the piece on the bus came true in the cancellation of the recording.

Another instance happened in the mid 1980s when the Condhong Raos group led by the late Ki Narta Sabda, was on tour in Papua, the easternmost Indonesian province. During the tour, they were supposed to accompany a wayang performance by Ki Narta Sabda, who was the most popular dhalang (puppeteer) at the time. In the afternoon, Pak Saguh said, the group was rehearsing for the performance and a person from Surabaya, East Java, was present during the rehearsal. It turned out that he loved the Gendhing Laler Mengeng, and requested the group to play it. The members of the group initially refused to perform it considering that it would have an evil effect on them. However, the man insisted and because the members of the group did not want to continue disputing with him they finally surrendered and played it. As they played, the members of the group and especially Pak Saguh and

2 The image of working in rice-field emanates from the term "pacul gowang," meaning "defected hoe". In villages, this image is commonly used to refer to the environment among farmers who work for the people. Here, villagers intend to produce rice (and other harvests as well) for the benefit of the people in the village. Peace and prosperity are the main goals of the people and this image is constantly envisioned in their efforts. When look for some better future people recall it to reach their goal. In this context, musicians intended to stop the rain to allow the audience to gather to learn the fundamental values in the community. This is the main reason why musicians intend to bring about the unity of the people in performance contexts. 
other senior musicians were thinking that something wrong was bound to happen after they played the sacred piece. That night, a couple of hours before the performance was to start, Pak Narta fell ill and was unable to perform the wayang. Being in a terrible shape, he asked Pak Saguh to replace him. The performance was a success but it left the image that Pak Narta was ill because of the effect of the gendhing they had played in the afternoon.

There are many other examples of gendhing with good or evil effects. The point I wish to make here is that in both cases mentioned above, the good and evil effects were meaningful because the people constructed the meaning of these gendhing in a particular way and under specific conditions which is connected to the way they think about people and God. We cannot underestimate this notion because for the worldviews of these people, these associations are personal and real. With these views in mind, the people can manage their performances and may expect something to happen so that their needs are met.

\section{COMMUNITIES' BEHAVIOUR}

When they gather together, village people often discuss the issue of gamelan and people's behaviour. While conducting research in the field, I could join in the discussions when villagers got together in small eating stalls and these meetings could last until after midnight. At the houses of the musicians and puppeteers the topic could be more complicated because they were really deeply involved in these kind of processes.

Even though stories about the connection between gamelan music and people's behaviour are widespread in villages there is no definite answer as to how the performances affect the behaviour of the people who listened to, or of the musicians who performed the music. The reason is that the effect of this communication process is wide ranging and varies from individual to individual and from one group of people to the next. To understand this, I asked Pak Jumadi (personal communication, 10 March 2005), a senior in Gombang village if a gamelan performance could influence the behaviour of people and if so, how this process happens and under what conditions. He responded that it could affect people's conduct but not in any direct and obvious way.

Pak Jumadi's response was right considering that a gamelan performance does not provide people with explicit directions to make them literally behave the way the gamelan musicians want. He believes that the performances may function as a medium for the musicians to emphasise the fundamental thoughts of the community. Village people often mention the significance of this connection because in this context they can find guidance for how to live their lives and discover the foundations of the values of the community. Scholars often discuss these issues to show the close relationship between these aspects of performances. Herbert Marcuse, for example, who shares Pak Jumadi's view, calls this indirect guidance "affirmative character" in which the gamelan music can emphasize the values prevalent in the community. 
Compared with Pak Jumadi's view, however, Marcuse's view affects this psychological state more intensely. He believes that the arts (gamelan, dance, and theatre) can function to "pacify rebellious desire" in order to find the best channel for what they experience in the community. Marcuse (1968: 121) wrote:

In affirmative culture even unhappiness becomes a means of subordination and acquiescence. By exhibiting the beautiful in the present, art pacifies rebellious desire.

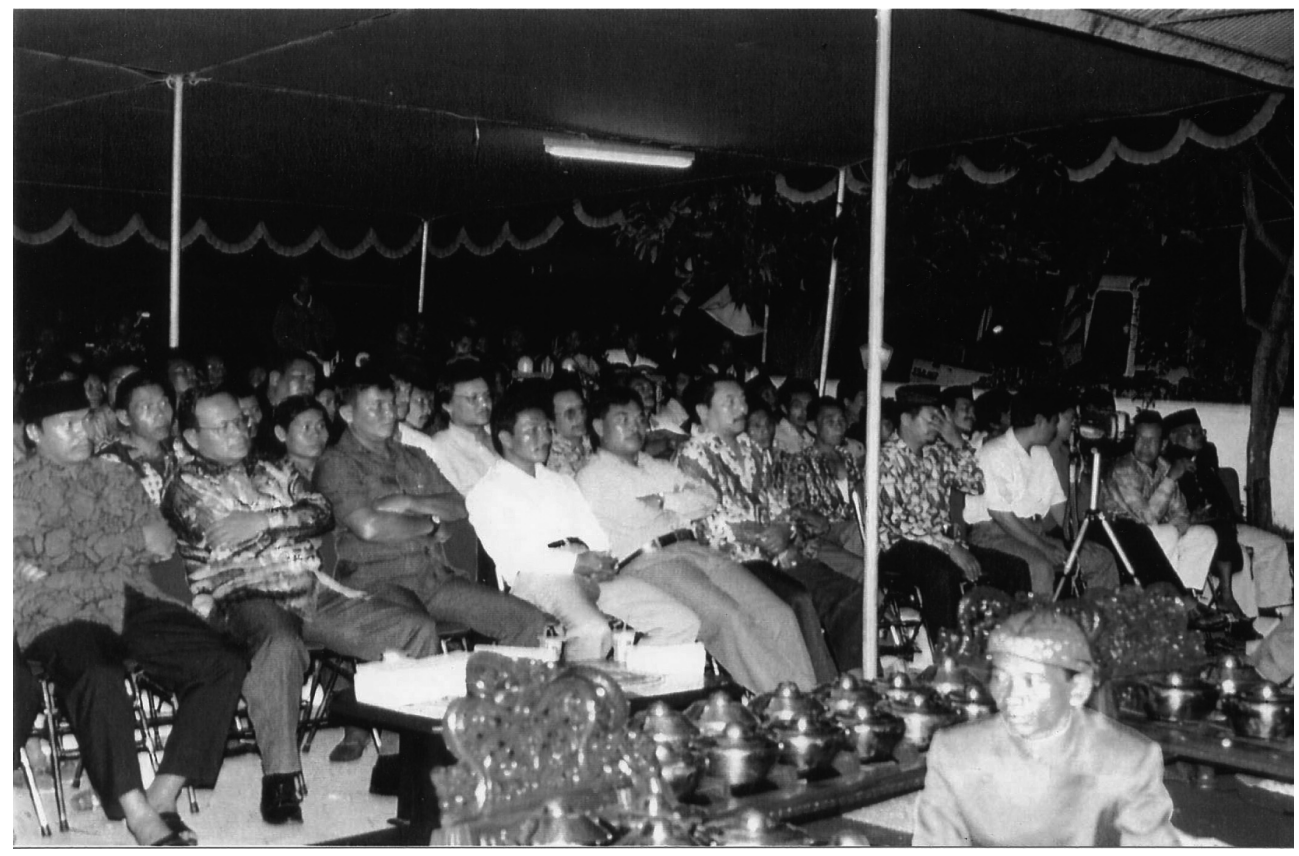

Illustration 2. Audience members enjoy the gamelan performance in the context of a village celebration to construct meanings; Photograph by the author.

Audiences attach deep meaning to these kinds of associations especially people who have a long experience in listening and watching gamelan performances (see Illustration 2). They often used these associations as a means to evaluate recent social conditions. In one interview (2 April 2006) in Delanggu, Central Java, Pak Sutadi very clearly mentioned the interrelationship between gamelan and the community's behaviour in grasping the meaning of the performances. This kind of making sense of performances is not uncommon in villages and people can readily use the image to "solve the problems" they face in daily life.

Villagers are aware of this situation and they use the connection as a guide to judge what is right and what is not in social contexts. This guide is so important that in a way it becomes a reference for the ideal values people can benefit from whenever they need them. I often hear musicians, singers, and hosts discuss these values in and outside performance contexts. For example, when responding to youngsters' negative behaviour, Pak Sutadi 
commented that they displayed this conduct because they do not internalize the values of gamelan performances (8 March 2006). He acknowledged that gamelan values could become references for their views and their conduct in the community.

Malcolm Budd offered the similar opinion that the effect of a musical performance in the minds of audiences can explicitly be felt. He thinks that musical performances may have the power to tranquilize psychological states of mind. However, he also extends the power of music to the opposite psychological domain that the Javanese community associates with malevolence. He believed that tragedy, which according to villagers is undesirable because of its potential evil effects, also has a positive effect on people's emotions. In response to this issue, he used the effect of catharsis as a means of purgation. Citing Aristotle's theory of catharsis he wrote:

The pathological theory of the effect of tragedy construes catharsis as purgation and represents tragedy as affording a pleasurable relief of its distinctive emotions by means of a previous excitation of them; the emotions are tranquilized after and because of a painful excitement of them (Budd 1995: 110).

I believe that the effect of listening to gamelan music can go even further because a performance can stimulate a sense of orderliness of thoughts. These thoughts eventually create an atmosphere in the social environment in which the members of the community can derive benefit from the performance. When asked how the people use the gamelan in this context, Pak Jumadi insisted that gamelan music induces a peaceful state of mind (nuwuhaken katentreman), a state of feeling that Javanese people aspire to. Especially in the village setting, peace is relevant because it is a crucial factor in the development of harmony among the villagers.

We need to raise a question though. How does this process take place in the minds of the audiences? The content of gamelan music does not exist in a vacuum but rather accentuates the norms prevalent in the community. Gamelan music highlights the musicians' ideas of what these significant values in social life are. It prevents negative impacts and at the same time "promotes" the community's ideals. In a way, this process underlines the "deep structure" of the essence of the audiences's worldview. The process goes further by letting the people in authority absorb this essence and enforce these supreme values in order to reach their ultimate goal. Especially in villages where audiences almost daily attend gamelan performances during ceremonies this process takes place almost naturally.

Further processes happen in which society's principles interact with the ideals of the musicians. This eventually stimulates a reciprocal process in which society's ideals re-emphasize those of the musicians during performances. During gamelan performances, this interactive process intensifies the views of both the musicians and the audiences. It is in this context that ideals from the past and those to come in the future construct new "moral standards" in which people acquire new experiences. I would like to show how this 
reciprocal process takes place during performances by using the lyrics of a song that is widely used in gamelan. Consider the following:

Nulada laku utama ([please] emulate good conduct)

Tumrape wong tanah Jawi (like other Javanese people)

Wong agung ing Ngeksi Ganda (like the king of Mataram [an old kingdom])

Panembahan Senapati [the name of the king]

Kepati amarsudi (he is making good efforts)

Sudane hawa lan napsu (to hold desire in check)

Pinesu tapa brata (he devoted himself to meditation)

Tanapi ing siyang ratri (all day and night)

Amemangun karyenak tyasing sasama. (he wants to please others)

This text is widely used not only in gamelan performances but also during many other events such as macapatan (singing songs for pleasure or for a special purpose) where people get together during ritual celebrations. Although many other texts are available, people prefer this text because it has a specific meaning for villagers. It contains the worldview of the people where they can "mirror" conduct and thoughts in the right context. Here they will get the sense of struggling for a better future, holding desire to get an improved mental attitude, meditation, and how to please other people in the community. All of these are the goals they want to attain in order to derive benefit for the future.

The following question may be asked. How do these meanings work in the context of society? This text contains the basic concepts, attitude, principles, and values suitable for the people. It affirms what people think and it underlies the behaviour of the people. Thus, the meanings of performances emphasize the values in the community and vice versa because the meanings of gamelan performances agree with society's values. Therefore, a gamelan performance mediates the exchange of "texts" in order to ensure that both the meanings of the gamelan and the values of the community reinforce each other. Sometimes, a performance also provides room for negotiation between the meaning of the performance and the values of the community.

\section{CLOSING REMARKS}

The communicative aspects of gamelan performances is a rare topic among scholars in the field of communication and art communities. Although few scholars are interested in the topic, it has become a central issue in the exchange of ideas between musicians and audiences. It is in this situation that gamelan performances come alive in the minds of audiences and people in villages.

Exploring how gamelan performances affect audiences' minds we find that the communicative aspect during performances is a crucial factor in order to understand the performances' contents. People in the community are aware of this process and they use the substance of the performances as fundamental values. More than that, the contents of gamelan music have become a central 
issue because they act as guides for the people in the community.

The next question then arises. In what way can a performance benefit musicians, audiences, hosts, and the members of society? As we understand it, a gamelan performance can be thought of as an aesthetic space in which audiences have the freedom to interpret the performance and construct its meanings. In a way, it is the transposition of the musicians' ideas into reality during performances and it is the articulation of thoughts using aesthetic modes. Therefore, the performances mediate the exchange of ideas between musicians on stage and audiences off stage. Using the performances, musicians and audiences can pursue their future goals for a better life.

\section{REFERENCES}

Albrecht, Milton C. 1970. "Arts as an institution", in: Milton C. Albrecht, James H. Barnett, and Mason Griff (eds), The sociology of art and literature; A reader, pp. 1-26. New York: Praeger.

Budd, Malcolm. 1995. Values of art; Pictures, poetry and music. New York: Penguin Book.

Marcuse, Herbert. 1968. Negations; Essays in critical theory. Translated by Jeremy J. Sapiro. London: Alien Lane.

Nattiez, Jean-Jacques. 1990. Music and discourse; Toward a semiology of music. Translated by Carolyn Abbatte. Princeton, New Jersey: Princeton University Press.

Santosa. 2001. Constructing images in Javanese gamelan performances: communicative aspects among musicians and audiences in village communities. $\mathrm{PhD}$ thesis, University of California Berkeley.

Santosa. 2008. "Menggagas komunikasi musikal dalam pertunjukan gamelan", Jurnal Ilmu Komunikasi Vol. 5/1: 65-80.

Sutrisno, Mudji. 1998. "Ruang estetik, oasis aksi kritik seni", in: Albert Camus et al., Seni, politik, pemberontakan, pp. v-xiv. Yogyakarta: Yayasan Bentang Budaya. 